\title{
Natural Water Quality and Its Suitability in the Northern Tianshan Catchments (Central Asia)
}

\author{
Bing-Qi Zhu ${ }^{1, \text { * }, \text { Yan Gao }}{ }^{2}$, Xiao-Jun Meng ${ }^{3}$ \\ ${ }^{1}$ Key Laboratory of Water Cycle and Related Land Surface Processes, Institute of Geographic Sciences and Natural Resources Research, \\ Chinese Academy of Sciences, Beijing, China \\ ${ }^{2}$ Centro de Investigaciones en Geografia Ambiental, Universidad Nacional Autonoma de Mexico, Campus Morelia, Mexico City, Mexico \\ ${ }^{3}$ The Development and Reform Committee of Xinjiang Uygur Autonomous Region, Urumqi, China
}

Email address:

zhubingqi@igsnrr.ac.cn (Bing-Qi Zhu)

${ }^{*}$ Corresponding author

\section{To cite this article:}

Bing-Qi Zhu, Yan Gao, Xiao-Jun Meng. Natural Water Quality and Its Suitability in the Northern Tianshan Catchments (Central Asia). Hydrology. Vol. 6, No. 1, 2018, pp. 32-42. doi: 10.11648/j.hyd.20180601.14

Received: November 2, 2017; Accepted: January 25, 2018; Published: February 23, 2018

\begin{abstract}
The use of water resources in arid lands is strongly limited by their quantity. To add to such knowledge, this study evaluates the natural water quality and its suitability for drinking, agricultural and industrial purposes in the northern Tianshan catchments (Central Asia), using chemical-physical indicators. The waters are neutral to alkaline and most of them are soft-fresh waters. The total dissolved solid (TDS) varies over two orders of magnitude. Much of the solutes and physicochemical parameters in water are under the highest desirable limits of the World Health Organization (WHO) for drinking purpose and most waters are of good water quality for irrigation. The effects of local pollution are minimal in the montane and piedmont areas of these watersheds but are significant in the oases and central areas of the drainage basins. Although the headwaters of the northern Tianshan catchments represent natural background conditions (soft-fresh water in salinity and hardness) and population densities within the catchment are relatively low, the river basin is facing relatively high anthropogenic pressure on water quality in the low reaches. The main contributors to the nutrient emissions are agricultural land use and, to a lesser extent, unban settlements with a high proportion of households without connection to wastewater treatment plants. Proposals for regional water resources management are advised, i.g. the geographic data and information should be detailedly included in the assessment and monitoring procedure, a water quality model should be built, and information technology such as visualization technology and the internet should be used.
\end{abstract}

Keywords: Natural Water, Water Quality, Drinking Water, Irrigation Water, Industrial Quality, Northern Tianshan Catchments

\section{Introduction}

Environmental pollution has become of public interest long time ago. Not only the developed countries have been affected by this environmental problem, but also the developing nations suffer the impact of pollution [1] [2] [3] [4], due to disordered economic growth associated with the exploration of virgin natural resources.

Among the environmental issues, water pollution affects human health and agricultural production to a high extent. Knowledge of water pollution and its environmental characteristics is thus vital to understand water suitability for various purposes [4] [5] [6]. Water quality is an indicator of water pollution. Natural water (surface water and groundwater) quality in an area is a function of physical, chemical, biological, and radiological characteristics of water [7] that are greatly influenced by geological formations, climate, and topography [3] [4] [8] [9] [10] [11] [12] [13] [14] [15] [16] [17] [18] [19] [20]. In addition, human activities such as industrialization, agriculture, mining, and urbanization produce effluents affect natural water quality [3] [4] [11] [21] [22] [23]. Normally, natural water contamination occurs gradually with little impact in the initial period of deterioration, but if it is not controlled at the right time, this 
water may not be suitable for any purpose for a long time [3] [6] [24]. Thus the importance of regular monitoring of natural water quality should be underlined, especially when there are significant changes in industrial, agricultural, and urbanization activities.

Over the past century, the world has experienced an undeniable temperature increase and thereby inevitably is faced with water environmental problems, which accelerate greatly in global water cycle processes [25] [26] [27] [28]. This is especially significant in arid lands of Central Asia, because most of natural waters in Central Asia originate from peripheral mountain glaciers [12] [13] [19] [20] and are fragile to global warming. Both of the quantity and quality of water resources in this context are the most important issues threatening the economic and social development of the Central Asian countries [29] [30] [31] [32], such as Nepal, India, Bangladesh and China, the pollution of rivers is severe and critical near urban stretches due to huge amounts of pollution caused by urban activities [31] [33]. An estimated 580 people in India die of water pollution related illnesses every day [34]. With the rapid economic growth in China, urban water quality is now facing serious challenges [35]. Approximately $90 \%$ of the water in the cities of China is polluted to varying degrees [36]. According to the 2009 statistics from the Ministry of Environmental Protection (MEP) of China, there were 80 water pollution accidents that year. In China's key cities, $27 \%$ of the centralized drinking water sources did not meet official standards, and half a billion Chinese had no access to safe drinking water [37]. Not only in Asia, water pollution is the leading cause of deaths and diseases worldwide. Across the globe, 6000 children die of diseases and 30 million people die of cancers caused by drinking polluted water each year [38]. In developing countries, $80 \%$ of human diseases is associated with polluted drinking water. Therefore, the quality of natural water is a powerful environmental determinant of health. The assurance of water use safety is a foundation for the prevention and control of waterborne diseases. Safe and clean water is a vital resource for everyone.

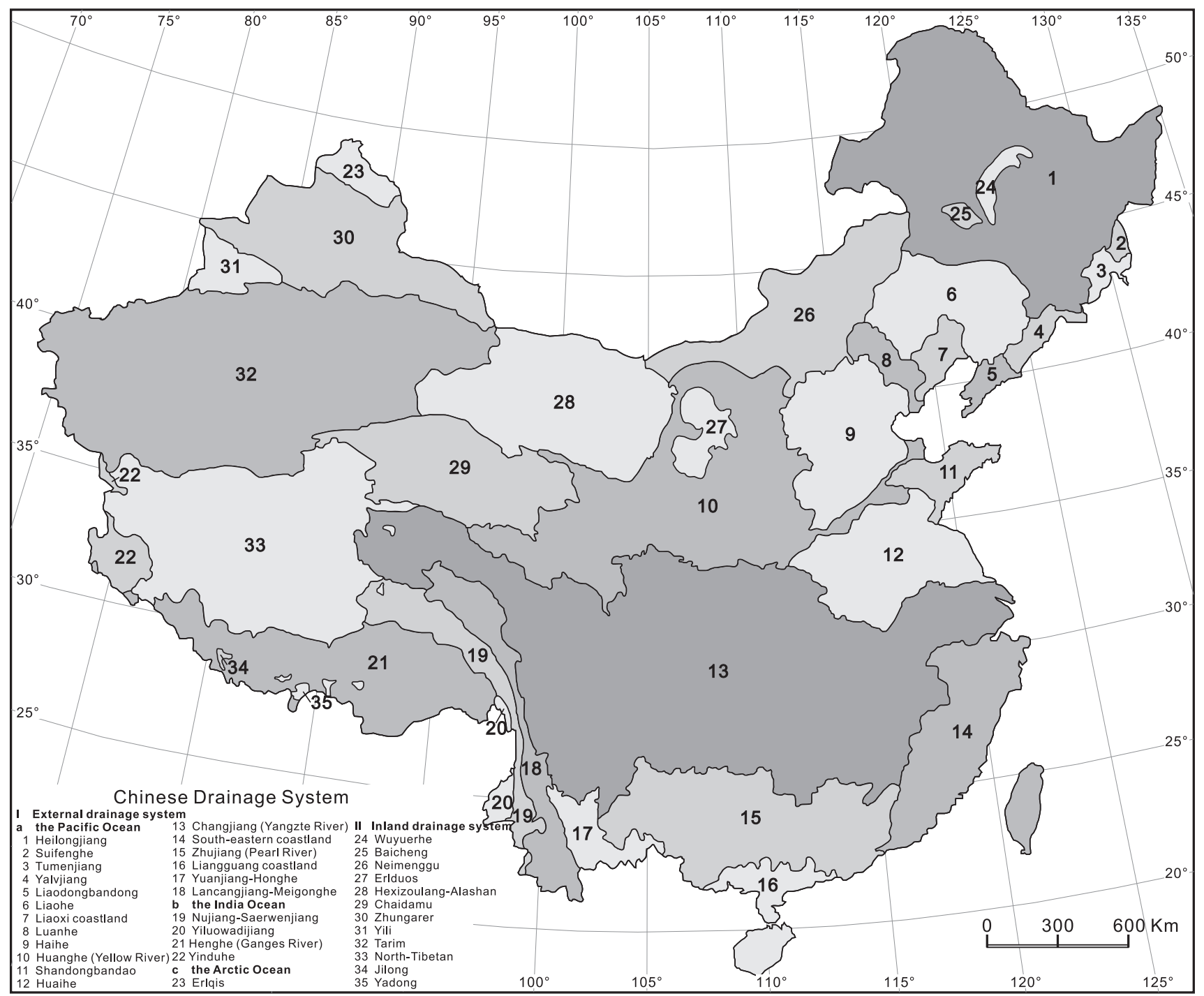

Figure 1. Geographical distribution of drainage systems in China. The 3 watersheds in northern Tianshan catchments of Central Asia, numbered 23, 30 and 31, are investigated in this study. 
The northern Tianshan catchments, including the Erlqis, Jungar and Yili watersheds in northern Xinjiang, northwestern China (No. 23, 30 and 31, respectively, in Figure 1), are large watersheds in Central Asia. These watersheds are extremely arid in climate and together represent one of the least-studied areas in China. At present, the northern Tianshan catchments is facing a tremendous change in climate and land-use intensification due to expansions in the agricultural sector, an increase of cattle and livestock and a growth of urban settlements due to migration of the rural population to the cities. It is expected that these may lead to unfavourable changes in natural water quality. In future, a possible strong need of water coming from other than mountain glaciers would result in a very expensive water collection system to supply the local population and economy. Therefore, it is essential to diagnose the quality of natural water for the regional water resource management. A key challenge is the identification of the main anthropogenic pollution sources and the assessment of their spatial distribution. Until now, however, despite continuing speculation about the evolution of water resource quantity in the northern Tianshan catchments, very little is known about the water quality of natural waters in these watersheds, because little information and chemical data are available within the international scientific literature with regard to this drainage system.
In order to add to such knowledge, this study investigates the geochemical solutes from the river water, groundwater, lakes and reservoirs in the northern Tianshan catchments and identify the main anthropogenic pollution sources and their spatial distribution. The water quality and its suitability for drinking, irrigation and industrial purposes in this region are emphasisly evaluated.

\section{Materials and Methods}

This study focuses on the northern Tianshan catchments in Central Asia. The drainage basin includes three watersheds, namely the Yili, Jungar and Erlqis watersheds. The study areas investigated lies between $78^{\circ}$ and $90^{\circ} \mathrm{E}$ and $42^{\circ}$ and $50^{\circ} \mathrm{N}$, covers an area of approximately $603,000 \mathrm{~km}^{2}$ and is bounded by the Tianshan Mountains to the south and by the Altai Mountains to the north. The Jungar watershed is the central part of the study area. It is formed by a structural depression filled with Quaternary and Tertiary unconsolidated sediments as much as $500-1000 \mathrm{~m}$ thick [11]. The large geographic distance from the surrounding oceans and the presence of the rain-shadow effect due to the surrounding orographic conditions are responsible for the arid climate of these watersheds [12] [20].

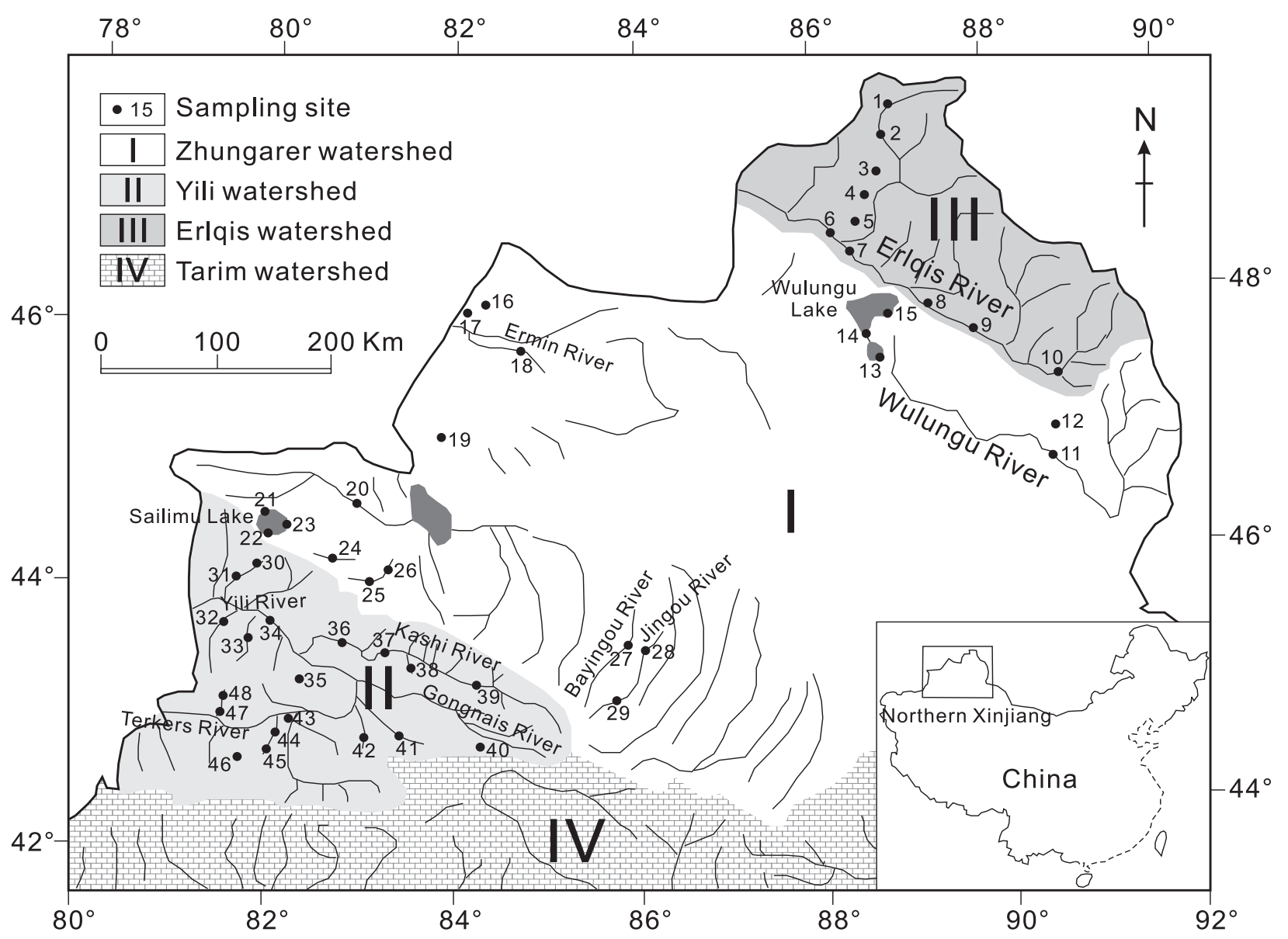

Figure 2. Map of the river distributions and sampling site locations of the 3 studied watersheds in the northern Tianshan catchments in Central Asia. 
These watersheds in Central Asia are controlled by an arid temperate continental climate. The mean annual air temperature is about $5^{\circ} \mathrm{C}$, with a minimum of $-10^{\circ} \mathrm{C}$ to $-20^{\circ} \mathrm{C}$ in January and a maximum of $28^{\circ} \mathrm{C}$ to $33^{\circ} \mathrm{C}$ in August [12]. The regional precipitation is derived mainly from the westerly winds, with a mean annual precipitation rate of $60-150 \mathrm{~mm}$ in the center desert and 200-500 in the surrounding mountainous areas [12] [13]. The potential evapotranspiration is approximately 1000-3500 mm/a [12]. The Yili and Jungar watersheds are inland watersheds and the Erlqis watershed is a tributary of the $\mathrm{Ob}$ River which drains into the Arctic Ocean [11].

Water sample locations were selected from various parts of the Erlqis, Jungar and Yili watersheds (Figure 2), including river stems, stream channels, hill slopes, wells, lakes, ponds, man-made trenches and reservoirs. The sampling sites were chosen carefully in order to maximise representation of the diverse ecohydrological environments within the river systems. Taking into account that the tributaries reflect a much broader variety of geologic, biologic, and population patterns than do main stem rivers [13] [39], it was of interest to sample tributary water to look for common features reflected in their hydrochemistry.

The physicochemical parameters such as temperature (T), $\mathrm{pH}$, electrical conductivity (EC), electrical potential (EP/Eh) and total dissolved solid (TDS) were measured in situ with a calibrated portable Multi-Parameter Analyzer (Eijkelkamp 18.28). The bias of the analytical procedures is $<2 \%$ for $\mathrm{pH}$ and EP, $<1 \%$ for EC, TDS and T. Alkalinity (as $\mathrm{HCO}_{3}{ }^{-}$) was determined with a Hach digital titrator using the Gran method (Wetzel and Likens, 2000) The concentrations of major cations $\left(\mathrm{Li}^{+}, \mathrm{Na}^{+}, \mathrm{NH}_{4}^{+}, \mathrm{K}^{+}, \mathrm{Mg}^{2+}, \mathrm{Ca}^{2+}\right)$ and anions $\left(\mathrm{F}^{-}, \mathrm{Cl}^{-}\right.$, $\mathrm{NO}_{2}^{-}, \mathrm{Br}^{-}, \mathrm{NO}_{3}^{-}, \mathrm{H}_{2} \mathrm{PO}_{4}^{-}, \mathrm{SO}_{4}{ }^{2-}$ ) were determined by ion chromatography (Dionex $600 \mathrm{IC})$ with deionized water $(\mathrm{EC}<$ $2.1 \mu \mathrm{S} / \mathrm{cm}$ ) as the dilute base. A balance of ionic charge and a conservation of mass occur, respectively, indicating a high reliability of the analytical data.

\section{Results}

The $\mathrm{pH}$ values of the selected water samples vary from 7.0 to 9.81 with an median value of 7.85 indicating that the waters are generally neutral to slightly alkaline. The TDS range between $24.6 \mathrm{mg} / \mathrm{L}$ and $6200 \mathrm{mg} / \mathrm{L}$, varying over two orders of magnitude from fresh (TDS $<1,000 \mathrm{mg} / \mathrm{l}$ ) to brackish $(1,000 \mathrm{mg} / \mathrm{l}<\mathrm{TDS}<10,000 \mathrm{mg} / \mathrm{l})$.

The variation of major cation $\left(\mathrm{Na}^{+}, \mathrm{K}^{+}, \mathrm{Ca}^{2+}\right.$ and $\left.\mathrm{Mg}^{2+}\right)$ and anion $\left(\mathrm{Cl}^{-}, \mathrm{HCO}_{3}{ }^{-}, \mathrm{SO}_{4}{ }^{2-}\right.$ and $\left.\mathrm{NO}_{3}{ }^{-}\right)$concentrations measured in the studied water samples is illustrated in the Box and Whisker plot (Figure 3), where $\mathrm{Ca}^{2+}$ and $\mathrm{HCO}_{3}^{-}$are the dominant cation and anion, respectively. Nevertheless, many of the water samples contained high $\mathrm{SO}_{4}{ }^{2-}$ concentrations. The order of relative abundance of major cations in these waters is $\mathrm{Ca}^{2+}>\mathrm{Na}^{+}>\mathrm{Mg}^{2+}>\mathrm{K}^{+}$(on $\mathrm{mg} / \mathrm{L}$ basis) while that of anions is $\mathrm{HCO}_{3}{ }^{-}>\mathrm{SO}_{4}{ }^{2-}>\mathrm{Cl}^{-}>\mathrm{NO}_{3}{ }^{-}$. Large percentages of contribution to the TDS of water samples are from $\mathrm{HCO}_{3}{ }^{-}, \mathrm{Ca}^{2+}$ and $\mathrm{SO}_{4}{ }^{2-}$.

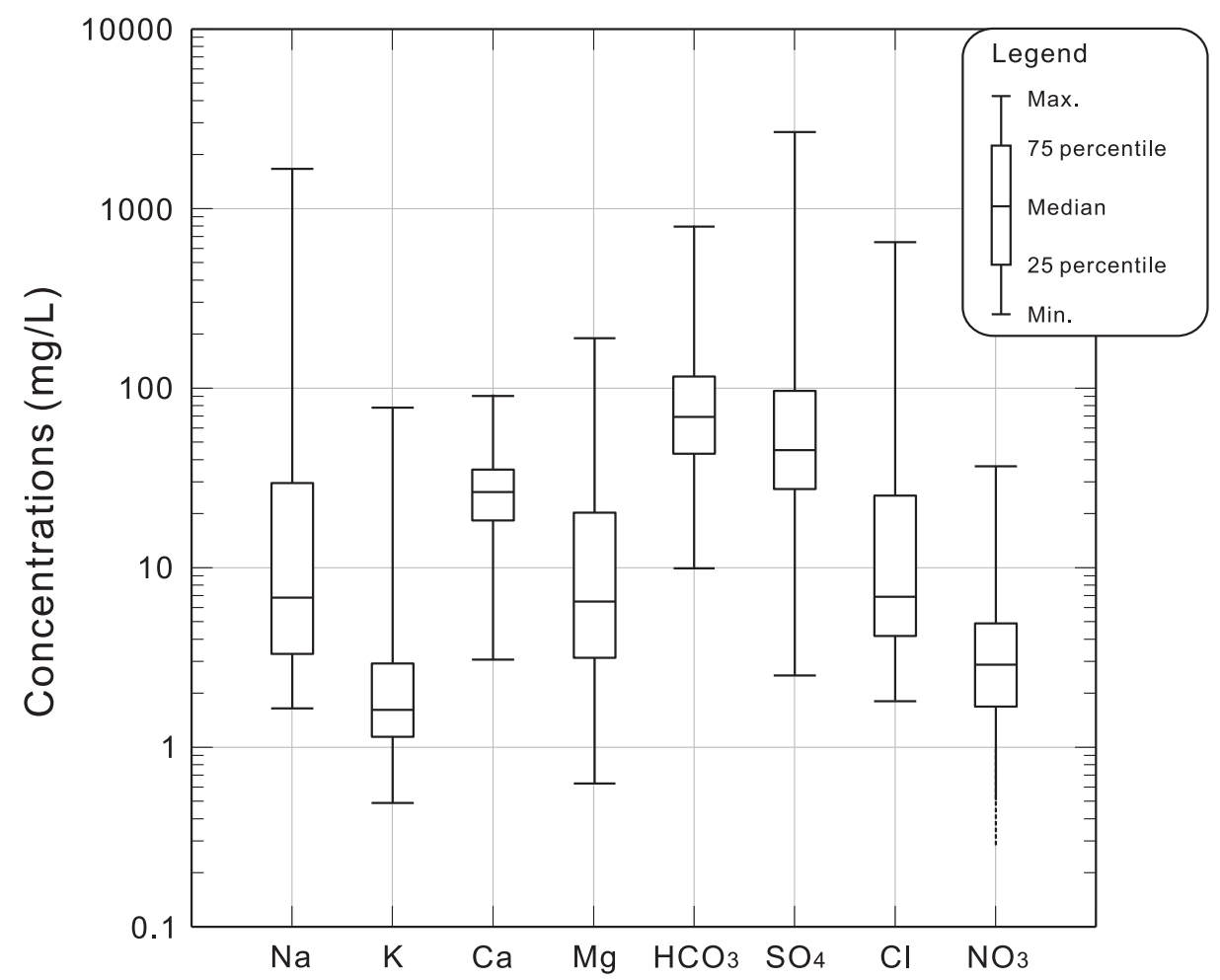

Figure 3. Box and Whisker plots showing the variation of major ion concentrations in the studied water samples.

The concentrations of major ions measured in the studied water samples are presented in the Piper Trilinear Plot (Figure
4). This figure shows that the natural waters in the study area can be broadly divided into 4 major types: type-1, $\mathrm{Ca}-\mathrm{HCO}_{3}$; 
type-2, Ca-Mg- $\mathrm{HCO}_{3}-\mathrm{SO}_{4}$; type-3, Ca-Mg-SO $\mathrm{S}_{4}$ and type-4, $\mathrm{Na}-\mathrm{SO}_{4}$. Major waters are of $\mathrm{Ca}-\mathrm{HCO}_{3}, \mathrm{Ca}-\mathrm{Mg}-\mathrm{HCO}_{3}-\mathrm{SO}_{4}$ and $\mathrm{Ca}-\mathrm{Mg}-\mathrm{SO}_{4}$ types and their chemical properties are dominated by alkaline earths and the $\mathrm{HCO}_{3}{ }^{-}$and $\mathrm{SO}_{4}{ }^{2-}$ anions. The $\mathrm{Na}_{-} \mathrm{SO}_{4}$ type water occupies the section near the right corner of the central diamond. These waters are of the saline water type. Water types distributed in the Erlqis and Yili watersheds are mainly type- 1 and type-2, while those in the Jungar watershed are type- 1 and type- 2 in the mountain areas and type- 3 and type- 4 in desert plain areas. In general, water types of the 3 watersheds display a kind of zonal distribution from mountainous area to pediment, to oases and to desert plain, namely a variational trend in rough order of type-1, type-2, type- 3 and type- 4 .

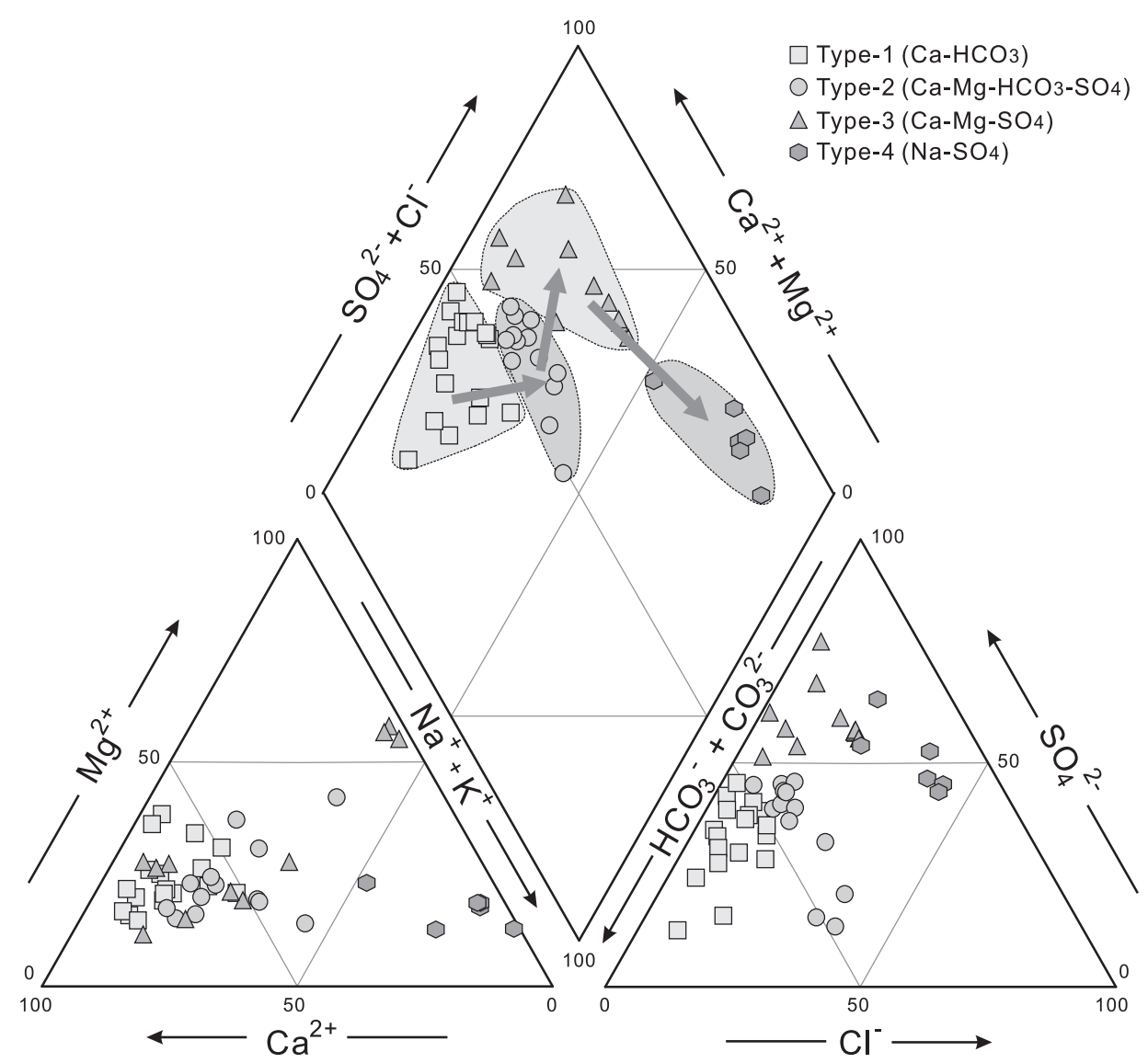

Figure 4. Piper diagram showing major ion composition of the natural waters in the northern Tianshan catchments in Central Asia.

\section{Discussion}

\subsection{Water Quality and Its Suitability for Drinking, Irrigation and Industrial Purposes}

Water quality refers to the chemical, physical, biological, and radiological characteristics of water [7] [40]. It is a measure of the condition of water relative to the requirements of one or more biotic species and or to any human need or purpose [40] [41] [42]. It is most frequently used by reference to a set of standards against which compliance can be assessed. The most common standards used to assess water quality relate to health of ecosystems, safety of human contact and drinking water. The World Health Organization (WHO) has produced international norms on water quality in the form of guidelines, which are used as the basic regulations and standards in developing and developed countries.

In this study, the natural water quality for drinking, irrigation and industrial purposes in the northern Tianshan catchments is assessed based on the recommended standards of the World Health Organization [38], the National Standard of the People's Republic of China [43] and the water quality criteria adopted by [44] and [45].

\subsubsection{Drinking Water Quality}

The total dissolved solids (TDS) versus the total hardness (TH) plot (Figure 5a) shows that most surface and groundwater samples in these watersheds are soft-fresh and hard-fresh water. Several water samples with high TDS $(>1000 \mathrm{mg} / \mathrm{L})$ and $\mathrm{TH}(>300 \mathrm{mg} / \mathrm{L})$ values, classed as hard-brackish water in Figure $5 \mathrm{a}$, are from the Jungar watershed. TDS, TH, $\mathrm{pH}$ and the concentrations of $\mathrm{Ca}^{2+}, \mathrm{Mg}^{2+}$, $\mathrm{Na}^{+}, \mathrm{Cl}^{-}, \mathrm{SO}_{4}{ }^{2-}, \mathrm{NO}_{3}{ }^{-}$and $\mathrm{F}^{-}$in about $0 \sim 20 \%$ of the studied water samples are higher than the highest desirable limits of $1000,450,8.5,75,30,200,250,250,50$, and $1.5 \mathrm{mg} / \mathrm{L}$ respectively, prescribed for drinking purpose by [38] and [43]. All groundwater samples in this study are below the limits of the [38] and [43]. This means that most of the surface waters $(80 \%)$ and all of groundwaters in the study area are suitable for drinking and domestic purposes. 

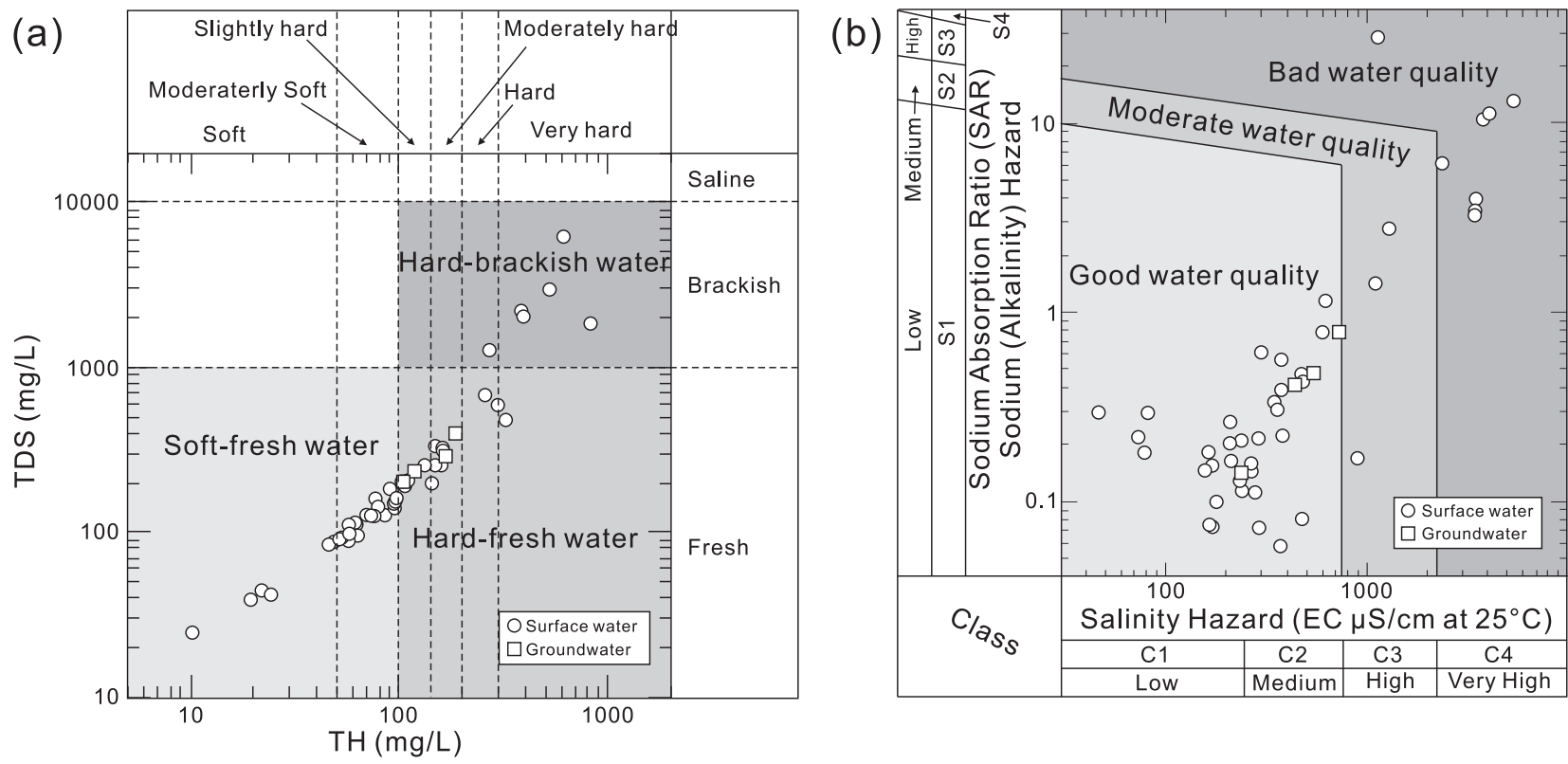

Figure 5. Natural water quality for drinking and irrigation purposes in the northern Tianshan catchments in Central Asia.

The classification of the studied natural waters based on total hardness $(\mathrm{TH})$ shows that $50 \%$ of the water samples fall in the soft category (Figure $5 \mathrm{a}, \mathrm{TH}<100 \mathrm{mg} / \mathrm{L}$ ) and $50 \%$ in the moderately to very hard (Figure $5 \mathrm{a}, \mathrm{TH}>100 \mathrm{mg} / \mathrm{L}$ ). In most of the water samples $(>87 \%)$, the alkaline earth metals exceed the alkalis metals $(\mathrm{Ca}+\mathrm{Mg}>\mathrm{Na}+\mathrm{K})$ (Figure 4) and also in a large part of water samples $(40 \%)$, the weak acid exceeds strong acids ( $\mathrm{HCO} 3>\mathrm{SO} 4+\mathrm{Cl}$ ) (Figure 4). Therefore, such water has only temporary hardness according to Handa's classification [46]. The maximum allowable limit of TH for drinking purpose by WHO is $500 \mathrm{mg} / \mathrm{L}$ and the most desirable limit is $100 \mathrm{mg} / \mathrm{L}$ [38]. According to this standard, $50 \%$ of the water samples in the northern Tianshan catchments is under the desirable limit and $90 \%$ of the water samples is under the maximum allowable limit, respectively.

\subsubsection{Irrigation Water}

To assess the water quality for irrigation purposes, the $\mathrm{Na}$ or alkali-hazard expressed in terms of sodium adsorption ratio (SAR) is widely used. If waters used for irrigation are high in $\mathrm{Na}^{+}$and low in $\mathrm{Ca}^{2+}$, the ion-exchange sites may become saturated with $\mathrm{Na}^{+}$, which destroys the soil structure, because of dispersion of the clay particles. Such soils reduce plant growth. The SAR for the studied waters is computed, using the formula (Hem, 1991): $\mathrm{SAR}=\mathrm{Na}^{+} /\left(\left(\mathrm{Ca}^{2+}+\mathrm{Mg}^{2+}\right) / 2\right)^{0.5}$, where the ion concentrations are expressed in meq/L. The computed SAR values for water samples in the 3 watersheds range from 0.06 to 28.3 , with an average value of 1.97 . The SAR versus EC plot (Figure 5b) shows that most surface water samples are of good water quality $(75 \%)$. A small number of surface water samples are of moderate quality (7\%) and poor quality (18\%) types. The 4 groundwater samples analyzed are all of good water quality. The moderate to bad quality waters have higher $\mathrm{Na}^{+}$concentrations.

It is generally known that agricultural practices can pose a serious threat to natural water, particularly groundwater quality. It is especially true in arid areas as the growing season with its high water demands coincides with the dry period. In addition, the use of fertilizers with a strong polluting effect on groundwater is a widespread agricultural practice in northwestern China. The use of $\mathrm{N}$ fertilizers in particular is well established throughout the world and increased use has led to extremely high $\mathrm{NO}_{3}{ }^{-}$concentrations in groundwaters [47] [48] [49]. Compared with the $\mathrm{NO}_{3}{ }^{-}$contents $(0.5 \sim 7.7$ $\mathrm{mg} / \mathrm{L})$ in the studied surface waters, groundwater samples (such as samples 16, 25, 26) collected from different irrigated oases in the Jungar watershed have evidently higher concentrations of $\mathrm{NO}_{3}{ }^{-}(22-37 \mathrm{mg} / \mathrm{L})$, indicating the strong influence of local agricultural practices in these zones.

The three inorganic $\mathrm{N}$ species $\left(\mathrm{NO}_{3}^{-}, \mathrm{NO}_{2}^{-}, \mathrm{NH}_{4}{ }^{+}\right)$have different measured distributions in the studied waters. Nitrite was not detected in any sample, and $\mathrm{NH}_{4}{ }^{+}$only occurred in a few samples in this study. Nitrate was detected in most of the studied samples. Its concentrations do not show any systematic variations with any ion concentrations and parameters or along the river courses, suggesting that point sources, presumably of anthropogenic origin, play an important role. In comparison with the mean value $(2.46 \mathrm{mg} / \mathrm{L})$ of $\mathrm{NO}_{3}{ }^{-}$in this study, somewhat higher concentrations of $\mathrm{NO}_{3}{ }^{-}$ $(7 \sim 37 \mathrm{mg} / \mathrm{L})$ were observed in several studied samples collected from oases with a dense population or farming, particularly groundwater and river water taken from agricultural and residential regions. This indicates an evident anthropogenic input of $\mathrm{NO}_{3}^{-}$in these places, probably from agricultural activities (fertilizers) or municipal and industrial discharges. These inputs are possibly modified by biological processes in the river itself, with oxidation of $\mathrm{NH}_{4}^{+}$to $\mathrm{NO}_{2}^{-}$ and subsequently to $\mathrm{NO}_{3}^{-}$[39] [50] [51], which could explain the distribution patterns of the 3 inorganic $\mathrm{N}$ species in the 
studied waters.

\subsubsection{Water Quality for Industrial Use}

Industries frequently suffer from the common undesirable effects of incrustation and corrosion, which are the chemical reactions caused by inferior water quality. The incrustation involves a deposition of undesired material of $\mathrm{CaCO}_{3}$ on surface of metals, while the corrosion is a chemical action on metals that results in the metal being eaten away.

The quality requirements for industrial water supplies range widely. In this study, the following water quality criteria adopted by [44] and [45] are used to evaluate the incrusting and corrosive properties of the natural waters in the northern Tianshan catchments:

(1) Water, with $\mathrm{HCO}_{3}$ more than $400 \mathrm{mg} / \mathrm{l}$ or $\mathrm{SO}_{4}$ more than $100 \mathrm{mg} / \mathrm{l}$, may cause incrustation, and

(2) Water, with $\mathrm{pH}<7$ or TDS more than $1,000 \mathrm{mg} / \mathrm{l}$ or $\mathrm{Cl}$ more than $500 \mathrm{mg} / \mathrm{l}$, may cause corrosion.

According to the above two standards, the content of $\mathrm{HCO}_{3}$ exceeds the limit of $400 \mathrm{mg} / \mathrm{l}$ in approximately $4.17 \%$ of the natural water samples in the northern Tianshan catchments. The concentration of $\mathrm{SO}_{4}$ is more than $100 \mathrm{mg} / \mathrm{l}$ in approximately $25.0 \%$ of the natural water samples in the northern Tianshan catchments. Such natural water quality can develop incrustation on metal surfaces and hence is not recommend for industrial use.

The natural waters studied are free from corrosion, as the $\mathrm{pH}$ is more than 7 for all of the water samples. However, highly mineralized water, with TDS more than $1,000 \mathrm{mg} / \mathrm{l}$, is observed from approximately $16.67 \%$ of the total water samples in the northern Tianshan catchments. Therefore, water sample S12-S15, S19 and S21-S23 can cause corrosion on metal surfaces. In addition, except for the water sample S13-14 and S19, the concentration of $\mathrm{Cl}$ does not exceed the limit of $500 \mathrm{mg} / \mathrm{l}$ in the other water samples in the northern Tianshan catchments.

\subsection{Implication for Regional Water Resources Management}

The chemical speciation and fractionation of ions and nutrients fluxes in the natural waters in this study demonstrate the wide variety of point and diffuse sources impacting upon the water quality of the northern Tianshan catchments. The analytical dataset indicates that chemical solutes and nutrient inputs to the oasis areas in the central basin are significantly impacted by diffuse agricultural sources, which suggesting the mobilization of N-rich pore water from the surrounding agricultural catchment via through flow and groundwater flow pathways. Such relationships are well documented in the literature in agricultural catchments [52] [53] [54] [55] [56] [57] [58] [59]. However $\mathrm{N}$ flux from major point source discharges is also important in the northern Tianshan catchments, as is shown in the data for groundwater in the central Jungar watershed. At these sites the impact of this discharge on background hydrochemistry is evident with all $\mathrm{N}$ species concentrations.

In general, the basin-scale investigation for natural water quality in the northern Tianshan catchments shows that even though most rivers in the basin are in relatively pristine condition, at least $20 \%$ water samples in forty-eight rivers/lakes are potentially changed and/or polluted due to natural and anthropogenic factors, including the central Jungar oasis and surrounding tributaries. Physical-chemical analyses of the water samples taken in the Yili, Jungar and Erqis watersheds show a relative enrichment in total hardness (Figure 5) in comparison to natural background conditions and maximal permissible concentrations of the international standard of [38]. The remarkable increase of Nitrate-N concentration from 2.46 to $37 \mathrm{mg} / \mathrm{L}$ in the natural waters is an indication for the increasing nutrient release into oasis areas by diffuse sources, mainly urban areas without connection to treatment plants in the northern Tianshan catchments. For nutrients concentrations and loads, such as nitrogen and orthophosphate-P in arid land rivers, a similar trend between them has been observed [60]. As revealed by a nutrient emission modelling, urban settlements are generally the main sources for nitrogen and phosphorus emissions contributing about $55 \%$ (nitrogen) and $52 \%$ (phosphorus) of the total emissions [61]. The proportion of point sources (PS) was much higher for nitrogen (30\% of total $\mathrm{N}$ emissions) than for phosphorus (15\% of total Permissions). Since only about $35 \%$ of the total population in a river basin are connected to PSs, thus unconnected urban areas represent an important proportion of the total emissions (38\% of phosphorus and $25 \%$ of nitrogen emissions) [61]. However, this unconnected part is often disturbed by river bank erosion, which is another significant source of nutrient release [62] [63]. This process is triggered by an increasing degradation of riparian vegetation due to high livestock densities with free access to the running waters. Once the trends occur upstream, it help to explain the nutrient enrichment further downstream in the main stem, such as in the Selenga river [61].

The northern Tianshan catchments are an international drainage system in terms of water resources, which is shared between China (upstream) and Kazakstan (downstream) for the Yili watershed and between China (upstream) and Russia (downstream) for the Elqis watershed, respectively. By international standards, the northern Tianshan catchments is characterized by a relatively low mean population density of around 13.8 people $/ \mathrm{km}^{2}\left(<83.6\right.$ people $/ \mathrm{km}^{2}$ in Asia $)$ [64]. However, localized concentrations of population (such as 177.3 people $/ \mathrm{km}^{2}$ in the Urumqi City in the Jungar watershed), an often poor state of urban waste water infrastructures, high livestock densities in the riverine floodplains and large-scale mining activities are potential threats to the aquatic ecosystems in the northern Tianshan catchments. In the recent past, water quality monitoring in the China parts and the Kazakstan parts of the river basin was not harmonized, which is maybe best reflected by the fact that the two countries are located in the upstream and downstream sections of the Yili river watersheds, and thus faced different water resources problems. This followed by discrepancies in water policy objectives and understanding of monitoring purposes.

Therefore, the water quality analysis in this study indicates that water management in the northern Tianshan catchments 
faces several challenges. Such as in the Yili watershed, one of the three watersheds in the northern Tianshan catchments, the Yili River and its tributaries do not only constitute a transboundary river basin with a lack of harmonized monitoring; the large size, low population densities and challenges related to the political and economic transformation also result in a scarcity of environmental data. In such a situation, a comprehensive monitoring of water-resources is almost prohibitive. Therefore, one promising approach is to combine intensive monitoring in a representative model region with a more synoptic monitoring in the larger basin. This strategy seems plausible for the other two watersheds in the northern Tianshan catchments, which are comparable with regard to the (bio-) physical and socio-economic environment [11].

The current situation of natural water quality in the northern Tianshan catchments has potential implications for regional water resources management. It can be summarized briefly below.

(1) Natural water quality in the northern Tianshan catchments is characterized by geography, which depends on the location, and the conditions of the water source from which it is treated and transferred. The geographic data and information, which are strongly correlated with natural water quality, should be included in the assessment and monitoring of drinking, agricultural and industrial water quality in the regional and local management of water resources.

(2) With the development of infrastructure, natural water data are abundant in the northern Tianshan catchments, but the value of the information about water quality is poor. The comprehensive assessment and monitoring based on a water quality model should be built, as which will play an important role in ensuring safe and clean drinking, agricultural and industrial water in the future. For example, we can build a model based on combinational weighted aggregative index methods, which include two processes - the weight distributions of drinking, agricultural and industrial water indexes and comprehensive scores of these water qualities. In this model, the distribution of proper weights is a crucial procedure that greatly affects the comprehensive evaluation results. A small change of weight may cause a significant variation of the evaluation results. Subjective and objective weighting methods should be employed to obtain a new and robust weight distribution.

(3) The openness and transparency of water quality information to the public is beneficial to the improvement of water quality. For example, the United States has one of the safest water supplies in the world [7]. However, the national statistics in China do not specifically inform citizens on the quality and safety of the water coming out of the tap.

(4) Information technology, such as visualization technology and the internet, will make the assessment and monitoring of water quality more intuitive and convenient. The comprehensive assessment and monitoring of the drinking, agricultural and industrial water qualities in the northern Tianshan catchments will provide a powerful tool for government and health supervision agencies that need to make informed decisions.

\section{Conclusions}

This paper focused on the major ion chemistry of natural waters in the northern Tianshan catchments in northwestern China (Central Asia) to characterize their hydrogeochemistries and water qualities. Results show that the natural waters in the study areas are neutral to slightly alkaline in nature and most of them are soft-fresh water. The water salinities vary from fresh to brackish. Total dissolved solids (TDS), total hardness (TH), $\mathrm{pH}$ and the concentrations of $\mathrm{Ca}^{2+}, \mathrm{Mg}^{2+}, \mathrm{Na}^{+}, \mathrm{Cl}^{-}, \mathrm{SO}_{4}{ }^{2-}, \mathrm{NO}_{3}{ }^{-}$and $\mathrm{F}^{-}$in about $0 \sim 20 \%$ of the studied water samples are higher than the highest desirable limits of drinking water prescribed for drinking purpose by [38] and [43]. Most groundwater samples are below the limits of the [38] and [43]. Regards to the water quality for irrigation purposes, most surface water samples are of good water quality $(75 \%)$. A small number of surface water samples are of moderate quality $(7 \%)$ and poor quality (18\%). The groundwater samples are all of good water quality for irrigation purposes. The moderate to bad quality waters have higher $\mathrm{Na}^{+}$concentrations. Inorganic $\mathrm{N}$ demonstrates no statistically significant change in the study areas, but an increase in the lower reaches downstream from the Jungar watersheds, which may be due to urban expansion in the lower catchment. Point sources, presumably of anthropogenic origin, play an important role in oasis areas, but the effects of local pollution are minimal in the montane and piedmont areas. The current situation of natural water quality in the basin has potential implications for regional water resources management, i.g. the geographic data and information should be included in the assessment and monitoring of natural water quality in the regional and local management of water resources, a comprehensive assessment and monitoring based on a water quality model should be built, the water quality information should be open and transparent to the public and information technology such as visualization technology and the internet should be used for the assessment and monitoring of water quality in the basin.

\section{Acknowledgements}

This work was supported by the National Natural Science Foundation of China (41771014) and the National Key Research and Development Program of China (2016YFA0601900). The author is grateful to Profs. Xiaoping Yang and Xiaoguang Qin for their generous help in the research work.

\section{References}

[1] Listori JJ, World-wide Bank (1990) Environmental Health Components for Water Supply, Sanitation and Urban Projects. World-wide Bank, Washington, DC.

[2] Niemi GJ, Devore P, Detenbeck N, Taylor D, Lima A (1990) Overview of case studies on recovery of aquatic systems form disturbance. Environmental Management 14: 571-587. 
[3] Tomas D, Curlin M, Maric AS (2017) Assessing the surface water status in Pannonian ecoregion by the water quality index model. Ecological Indicators 79:182-190.

[4] Erickson JJ, Smith CD, Goodridge A, Nelson KL (2017) Water quality effects of intermittent water supply in Arraiján, Panama. Water Research 114:338-350.

[5] Cicchella D, Albanese S, De Vivo B, Dinelli E, Giaccio L, Lima A, Valera P (2010) Trace elements and ions in Italian bottled mineral waters: identification of anomalous values and human health related effects. Journal of Geochemical Exploration 107 (3):336-349.

[6] Misaghi F, Delgosha F, Razzaghmanesh M, Myers B (2017) Introducing a water quality index for assessing water for irrigation purposes: A case study of the Ghezel Ozan River. Science of The Total Environment 589:107-116.

[7] Diersing N (2009) Water Quality: Frequently Asked Questions. Florida Keys National Marine Sanctuary, Key West, FL.

[8] Helena B, Pardo R, Vega M, Barrado E, Fernandez J (2000) Temporal evolution of groundwater composition in an alluvial aquifer (Pisuerga River, Spain) by principal component analysis. Water Research 34 (3):807-816.

[9] Subramani T, Elango L, Damodarasamy SR (2005) Groundwater quality and its suitability for drinking and agricultural use in Chithar River Basin, Tamil Nadu, India. Environmental Geology 47 (8):1099-1110.

[10] Zhu B, Yang X (2007) The ion chemistry of surface and ground waters in the Taklimakan Desert of Tarim Basin, western China Chinese Science Bulletin 52: 2123-2129.

[11] Zhu B, Yang X, Rioual P, Qin X, Liu Z, Xiong H, Yu J (2011) Hydrogeochemistry of three watersheds (the Erlqis, Zhungarer and Yili) in northern Xinjiang, NW China. Applied Geochemistry 26:1535-1548.

[12] Zhu B, Yu J, Qin X, Rioual P, Xiong H (2012) Climatic and geological factors contributing to the natural water chemistry in an arid environment from watersheds in northern Xinjiang, China. Geomorphology 153-154:102-114.

[13] Zhu B, Yu J, Qin X, Rioual P, Liu Z, Zhang Y, Jiang F, Mu Y, Li H, Ren X, Xiong H (2013a) The Significance of mid-latitude rivers for weathering rates and chemical fluxes: evidence from northern Xinjiang rivers. Journal of Hydrology 486:151-174.

[14] Zhu B, Yu J, Qin X, Rioual P, Zhang Y, Liu Z, Mu Y, Li H, Ren $\mathrm{X}$, Xiong $\mathrm{H}$ (2013b) Identification of rock weathering and environmental control in arid catchments (northern Xinjiang) of Central Asia. Journal of Asian Earth Sciences 66:277-294.

[15] Balasubramanian N, Sivasubramanian P, Soundranayagam J, Chandrasekar N, Gowtham B (2015) Groundwater classification and its suitability in Kadaladi, Ramanathapuram, India using GIS techniques. Environmental Earth Sciences 57:1-23.

[16] Zhu B, Wang Y (2016a) Statistical study to identify the key factors governing ground water recharge in the watersheds of the arid Central Asia. Environmental Monitoring and Assessment 188 (1):66, doi: 10.1007/s10661-015-5075-4.

[17] Zhu B, Wang Y (2016b) Statistical study to identify the key factors governing ground water recharge in the watersheds of the arid Central Asia. Environmental Monitoring and Assessment 188 (4):210, doi: 10.1007/s10661-016-5205-7.
[18] Zhu B, Yu J, Rioual P (2016c) Geochemical signature of natural water recharge in the Jungar Basin and their response to climate. Water Environment Research, 88 (1):79-86.

[19] Zhu B, Yu J, Rioual P, Gao Y, Zhang Y, Xiong H (2015) Climate Effects on Recharge and Evolution of Natural Water Resources in middle-latitude Watersheds Under Arid Climate. In: Ramkumar $\mathrm{M}$ et al. (Eds) Environmental Management of River Basin Ecosystems, Springer Earth System Sciences. Pp. 91-109.

[20] Zhu B, Wang X, Rioual P (2017) Multivariate Indications between environment and ground water recharge in a sedimentary drainage basin in northwestern China. Journal of Hydrology 549:92-113.

[21] Dinelli E, Lima A, De Vivo B, Albanese S, Cicchella D, Valera P (2010) Hydrogeochemical analysis on Italian bottled mineral waters: effects of geology. Journal of Geochemical Exploration 107 (3):317-335.

[22] Singh A, Mondal GC, Singh TB, Singh S, Tewary BK, Sinha A (2012) Hydrogeochemical processes and quality assessment of groundwater in Dumka and Jamtara districts, Jharkhand, India. Environmental Earth Sciences 67 (8):2175-2191.

[23] Oyarzun R, Jofre E, Morales P, Maturana H, Oyarzun J, Kretschmer N, Aravena R (2015) A hydrogeochemistry and isotopic approach for the assessment of surface watergroundwater dynamics in an arid basin: the Limar1' watershed, North-Central Chile. Environmental Earth Sciences 73 (1):3955 .

[24] Rao YS, Reddy TV, Nayudu PT (1997) Groundwater quality in the Niva River basin, Chittoor district, Andhra Pradesh, India. Environmental Geology 32 (1):56-63.

[25] Menzel L, Burger G (2002) Climate change scenarios and runoff response in the Mulde catchment (southern Elbe, Germany). Journal of Hydrology 267:53-64.

[26] Roudier P, Ducharne A, Feyen L (2014) Climate change impacts on runoff in West Africa: a review. Hydrology \& Earth System Sciences 18 (7):2789-2801.

[27] Wangerlandsson L, Van dERJ, Gordon LJ, Savenije HHG (2014) Contrasting roles of interception and transpiration in the hydrological cycle - Part 1: Simple Terrestrial Evaporation to Atmosphere Model. Earth System Dynamics 5 (1):441-469.

[28] Oisson T, Jakkila J, Veijalainen N, Backman L, Kaurola J (2015) Impacts of climate change on temperature, precipitation and hydrology in Finland - studies using bias corrected Regional Climate Model data. Hydrology \& Earth System Sciences Discussions 12 (3):2657-2706.

[29] Ososkova T, Gorelkin N, Chub V (2000) Water Resources of Central Asia and Adaptation Measures for Climate Change. Environmental Monitoring and Assessment 61 (1):161-166.

[30] Food and Agriculture Organization (2003) Land Degradation Assessment in Drylands (LADA). FAO AGLL Technical Report. State Design and Research. Uzgipromeliovodkhoz Institute, Ministry of Agriculture and Water Resources; Tashkent Republic of Uzbekistan. 43 pp.

[31] Crosa G, Froebrich J, Nikolayenko V, Stefani F, Galli P, Calamari D (2006) Spatial and seasonal variations in the water quality of the Amu Darya River (Central Asia). Water Research 40:2237-2245. 
[32] Bezborodov GA, Shadmanov DK, Mirhashimov RT, Yuldashev T, Qureshi AS (2010) Mulching and water quality effects on soil salinity and sodicity dynamics and cotton productivity in Central Asia. Agriculture Ecosystems \& Environment 138 (1-2):95-102.

[33] Yadav SS, Rajesh K (2011) Monitoring water quality of Kosi River in Rampur District, Uttar Pradesh, India. Advances in Applied Science Research 2 (2):197-201.

[34] Rahman MM, Mandal BK, Chowdhury TR, Sengupta MK, Chowdhury UK, Lodh D, Chanda CR, Basu GK, Mukherjee SC, Saha KC, Chakraborti D (2003) Arsenic groundwater contamination and sufferings of people in North 24-Parganas, one of the nine arsenic affected districts of West Bengal, India. Journal of Environmental Science and Health Part A: Toxic/Hazardous Substances and Environmental Engineering 38 (1):25-59.

[35] Yan W, Li J, Bai X (2016) Comprehensive assessment and visualized monitoring of urban drinking water quality. Chemometrics and Intelligent Laboratory Systems 155:26-35.

[36] Huang F, Wang XQ, Lou LP, Zhou ZQ, Wu JP (2010) Spatial variation and source apportionment of water pollution in Qiantang River (China) using statistical techniques. Water Research 44 (5):1562-1572.

[37] Moe CL, Rheingans RD (2006) Global challenges in water, sanitation and health. Journal of Water and Health 4 (Suppl 1):41-57.

[38] WHO (2008) Guidelines for Drinking Water Quality. World Health Organization, Geneva.

[39] Pawellek F, Frauenstein F, Veizer J (2002) Hydrochemistry and isotope geochemistry of the upper Danube River. Geochimica \& Cosmochimica Acta 66:3839-3854.

[40] Dragun Z, Kapetanovic D, Raspor B, Teskeredzic E (2011) Water Quality of Medium Size Watercourse Under Baseflow Conditions: The Case Study of River Sutla in Croatia. Ambio 40 (4):391-407.

[41] Johnson DL, Ambrose SH, Bassett TJ, Bowen ML, Crummey DE, Isaacson JS, Johnson DN, Lamb P, Saul M, Winter-Nelson AE (1997) Meanings of environmental terms. Journal of Environmental Quality 26:581-589.

[42] Dragun Z, Tepic N, Krasnici N, Teskeredzic E (2016) Accumulation of metals relevant for agricultural contamination in gills of European chub (Squalius cephalus). Environmental Science \& Pollution Research International 23 (16):1-14.

[43] NSPRC (2002) Standards for Drinking Water Quality (GB3828-2002). National Standard of People's Republic of China.

[44] Johnson EE (1983) Groundwater and wells. Ist Indian edition, Jain Brothers, $440 \mathrm{p}$.

[45] Subba Rao N, Surya Rao P, Venktram Reddy G, Nagamani M, Vidyasagar G, Satyanarayana NLVV (2012) Chemical characteristics of groundwater and assessment of groundwater quality in Varaha River Basin, Visakhapatnam District, Andhra Pradesh, India. Environ Monitoring and Assessment 184:5189-5214.

[46] Handa BK (1964) Modified classification procedure for rating irrigation waters. Soil Science 68 (4):264-269.

[47] Stigter TY, Van Ooijen SPJ, Post VEA, Appelo CAJ, Dill
AMMC (1998) A hydrogeological and hydrochemical explanation of the groundwater composition under irrigated land in a Mediterranean environment, Algarve, Portugal. Journal of Hydrology 208:262-279.

[48] Sebilo M, Mayer B, Nicolardot B, Pinay G, Mariotti A (2013) Long-term fate of nitrate fertilizer in agricultural soils. Proceedings of the National Academy of Sciences of the united States of America 110 (45):18185.

[49] Castellano MJ, David MB (2014) Long-term fate of nitrate fertilizer in agricultural soils is not necessarily related to nitrate leaching from agricultural soils. Proceedings of the National Academy of Sciences of the united States of America 111 (8):E766.

[50] Kuzyk ZA, Macdonald RW, Granskog MA, Scharien RK, Galley RJ (2008) Sea ice, hydrological, and biological processes in the Churchill River estuary region, Hudson Bay. Estuarine Coastal \& Shelf Science 77 (3):369-384.

[51] Shi Y, Mangal V, Gueguen C (2016) Influence of dissolved organic matter on dissolved vanadium speciation in the Churchill River estuary (Manitoba, Canada). Chemosphere 154:367-374.

[52] Johnes PJ, Burt TP (1991) Water quality trends in theWindrush catchment: nitrogen speciation and sediment interactions. IAHS Publ 203:349-57.

[53] Johnes PJ, Burt TP (1993) Nitrate in surface waters. In: Burt TP, Heathwaite AL, Trudgill ST (eds) Nitrate: processes, patterns and control. Chichester, Wiley. p. 269-320.

[54] Heathwaite AL, Johnes PJ (1996) Contribution of nitrogen species and phosphorus fractions to stream water quality in agricultural catchments. Hydrological Processes 10:971-83.

[55] Jarvie HP, Neal C, Williams RJ, Neal M, Wickham HD, Hill LK (2002) Phosphorus sources, speciation and dynamics in the lowland eutrophic River Kennet, UK. Science of the Total Environment 282:175-203.

[56] Jarvie HP, Neal C, Withers PJA, Wescott C, Acornley RA (2005) Nutrient hydrochemistry for a groundwater-dominated catchment: the Hampshire Avon, UK. Science of the Total Environment 344:143-58.

[57] Johnson AG, Glenn CR, Burnett WC, Peterson RN, Lucey PG (2008) Aerial infrared imaging reveals large nutrient - rich groundwater inputs to the ocean. Geophysical Research Letters 35 (15):105-116.

[58] Peterson B, Stubler A, Wall C, Gobler C. Nitrogen-rich groundwater intrusion affects productivity, but not herbivory, of the tropical seagrass Thalassia testudinum. Aquatic Biology $15(1): 1-9$.

[59] Stelzer R, Bartsch L (2015) Nitrate removal in deep sediments of a nitrogen - rich river network: A test of a conceptual model. Journal of Geophysical Research Biogeosciences 117 (G2):2027.

[60] Hofmann J, Rode M, Theuring P (2013) Recent developments in river water quality in a typical Mongolian river basin, the Kharaa case study. Proceedings of the IAHS-IAPSO-IASPEI Assembly, Gothenburg, Sweden.

[61] Hofmann J, Hurdler J, Ibisch R, Schaffer M, Borchardt D (2011) Analysis of recent nutrient emission pathways, resulting surface water quality and ecological impacts under extreme continental climate: The Kharaa River Basin (Mongolia). International Review of Hydrobiology 96 (5):484-519. 
[62] Hartwig M, Theuring P, Rode M, Borchardt D (2012) Suspended sediments in the Kharaa River catchment (Mongolia) and its impact on hyporheic zone functions. Environmental Earth Sciences 65:1535-1546.

[63] Theuring P, Rode M, Behrens S, Kirchner G, Jha A (2013) Identification of fluvial sediment sources in a meso-scale catchment, Northern Mongolia. Hydrological Processes 27:845-856.

[64] Deng D, Duan H (2009). The problem of the population development and the characteristics of the population space distriubtion in urban regions of northern Xinjiang. Journal of Arid Land Resources and Environment 23 (8):53-60. 